\title{
The Role of Sulphate Reducing Bacteria in the Deterrioration of Oil Facilities; An Engineering Insight
}

\author{
Iweriolor Sunday, Emereje Peter \\ Department of Mechanical Engineering, School of Engineering, Delta State Polytechnic, Ogwashi-uku, Delta State, Nigeria
}

Email address:

trevklin@yahoo.com (I. Sunday), peteremereje@yahoo.com (E. Peter)

\section{To cite this article:}

Iweriolor Sunday, Emereje Peter. The Role of Sulphate Reducing Bacteria in the Deterrioration of Oil Facilities; An Engineering Insight. International Journal of Materials Science and Applications. Vol. 4, No. 3, 2015, pp. 213-218. doi: 10.11648/j.ijmsa.20150403.20

\begin{abstract}
The paper describes an advanced approach in the analysis and control of corrosion resulting from the activities of sulphate reducing bacteria as well as the reacting species in the development of the biofilm. An anaerobic Cultured medium was prepared and the $\mathrm{pH}$ read on a scale was 7.4 and medium after incubation was dispensed into five anaerobic experimental pipe and the respective biocides (formaldehyde, polyamine, diamine, biguanide and cow urine) at different concentration ranging from $5 \mathrm{mg} / 1$ to $580 \mathrm{mg} / 1$. Statistical procedures were also used to determine the correlation coefficient, coefficient of determination and polynomial equation generated on the basis of related information. The activities of the sulphate reducing bacteria results in the loss of weight of the coupons inserted and was found to be less in the experimental pipe with cow urine treatment.
\end{abstract}

Keywords: Bacteria, Cathodic Polarization, Microbial Corrosion, Biofilm, Coupons, Biocides, Pipelines, Weight Loss

\section{Introduction}

The deterioration of oil facilities resulting from the metabolic activities of the anaerobic types of organism especially the sulphate reducing bacteria accounts for more than half of the microbial influence on the corrosion of oil pipeline. They are obligate anaerobes and are heterotrophic in that they do not need oxygen to survive and as such they obtain their carbon and energy from organic nutrients, they use sulphur, sulphate or oxides of sulphur compound as oxidizing agents when decomposing oil pipelines. In natural conditions, they grow in association with other microorganism and a range of carboxylic and fatty acids which are common by-product of other micro-organism (Hamilton 1983).

These micro-organism uses their hydrogenase to consume the hydrogen $\left(\mathrm{H}_{2}\right)$ formed, thus impeding the formation of the passivation film as can be seen from the reactions below, this process is known as cathodic depolarization. The water undergoes dissociation and hydrogen ions are generated as shown in equation

$$
8 \mathrm{H}_{2} \rightarrow 8 \mathrm{OH}^{-}+8 \mathrm{H}^{+}
$$

Anodic reactions with the metals with the metal also generates electrons

$$
4 \mathrm{Fe} \rightarrow 4 \mathrm{Fe}^{2+}+8^{\mathrm{e}-}
$$

The hydrogen ion generated xcombines cathodically with the electrons to form a hydrogen atom which then forms molecular hydrogen.

$$
\begin{gathered}
8 \mathrm{H}^{+}+8^{\mathrm{e}-} \rightarrow 8 \mathrm{H} \\
8 \mathrm{H} \rightarrow 4 \mathrm{H}_{2}
\end{gathered}
$$

This process is susceptible to a mechanism of self control (passivation) in which the metal becomes immune to further corrosion that takes effect when the layer of $\mathrm{H}_{2}$ formed over the metal surface, thus reducing the metal flow from the anode to the cathode region.

The main corrosion products are metal hydroxide

$$
3 \mathrm{Fe}^{2+}+6 \mathrm{OH}^{-} \rightarrow 3 \mathrm{Fe}(\mathrm{OH})_{2}
$$

The destruction of the passivation film then occurs as a result of their

Hydrogenase (cathodic depolarization)

$$
\mathrm{S}_{4}{ }^{2-}+8 \mathrm{H} \rightarrow \mathrm{S}^{2-}+4 \mathrm{H}_{2} \mathrm{O}
$$


They generate hydrogen sulphide $\left(\mathrm{H}_{2} \mathrm{~S}\right)$ as a metallic product, that by dissociation increases the concentration of $\mathrm{H}^{+}$ions in the cathodic area

$$
\mathrm{H}_{2} \mathrm{~S} \rightarrow \mathrm{S}^{2-}+2 \mathrm{H}^{+}
$$

They indirectly interfere with anodic depolarization where the sulphide ions releases combines with the $\mathrm{Fe}^{2+}$ in the anode to form a new corrosion product (iron sulphide).

$$
\mathrm{S}^{2-}+\mathrm{Fe}^{2+} \rightarrow \mathrm{FeS}
$$

$\mathrm{Fe}_{2} \mathrm{~S}$ is cathodic to steel and will characteristically cause a pitting corrosion to occur in areas where it becomes associated with metals. The reaction of $\mathrm{H}_{2} \mathrm{~S}$ with iron also release hydrogen ions that can enter the microstructure of the pipe and cause it to become brittle commonly known as hydrogen embrittlement or even cause cracking or rapture of the pipe (King and Miller, 1971).

Sulphate reducing bacteria are anaerobic bacteria that can be isolated from variety of sub surface environments, if the aerobic respiration rate within the biofilm is greater than the oxygen diffusion rate during biofilm formation, the metal/biofilm interface can become anaerobic and provide a niche for sulphide production by the sulphate bacteria ( Pankhurst,1997)

The critical thickness of the biofilms required to produce anaerobic conditions depends on the availability of oxygen and the rate of respiration, the distribution of favorable $\mathrm{pH}$ ranges from 6-12, although they can mutate to accommodate $\mathrm{pH}$ conditions, they grow in soil, fresh water or salt water under anaerobic conditions. Many species of SRB have been identified, differing in morphology and organic substances that they can metabolize, they have in common the ability to oxidize certain organic substances to organic acids by reduction of inorganic sulfate to sulfide(Thomas, 1994)

In the absence of oxygen, the metabolic bye-product of these bacteria accumulates sulfide near the metal surface, this is evident when metal surface are covered with biofilms and the concentration of sulfide is highest near the metal surface.As already discussed, these micro-organisms exist in association with others and thereby feeding on mutual bye-products. Some component of slimes also uses nitrogen compound as an energy source, the bacteria nitrobacter is very efficient at destroying the corrosion inhibition properties of nitrite based inhibitors by oxidation. The bacteria of the genus Thiobacillus obtain energy by oxidation of inorganic sulphur compound to sulphuric acids as shown below

$$
\begin{gathered}
2 \mathrm{H}_{2} \mathrm{~S}+2 \mathrm{O}_{2}=\mathrm{H}_{2} \mathrm{~S}_{2} \mathrm{O}_{3}+\mathrm{H}_{2} \mathrm{O} \\
5 \mathrm{~S}_{2} \mathrm{O}_{3}{ }^{2-}+4 \mathrm{O}_{2}=\mathrm{H}_{2} \mathrm{SO}_{4}+4 \mathrm{~S} \\
4 \mathrm{~S}+3 \mathrm{O}_{2}+2 \mathrm{H}_{2} \mathrm{O}=2 \mathrm{H}_{2} \mathrm{SO}_{4}
\end{gathered}
$$

Worthy of note here is that these bacteria needs oxygen and a source of sulphur (opposite of SRB) and the end product is the sulphuric acid and hence some species of these bacteria remain active up to $\mathrm{pH}$ of 2 .

\subsection{Biofilm Development Stages}

The microbial induced corrosion process starts with a biofilm formation on the pipeline substrate, immobile cells attach to the steel substrate grow, reproduce and produce an extra-cellular polymeric substrate (EPS) that result in a complex biofilm formation. The biofilm formation encompasses three different stages, the first starts with the absorption of macromolecules by lipids, proteins, polysaccharides and human acids that functions as the conditioner of the pipeline surface. The presence of the macromolecules of varied concentration alters the physical and chemical properties of the pipeline material (Mansfield, 2007). At this stage, micro -organism, aqueous medium characteristics plays a significant role in the extent of adhesion, bacterial transfer rate and the resultant biofilm rate, the microbial characteristics includes surface charge, cell size and hydrophobicity, the surface properties may include chemical composition, inclusion, roughness, crevice, while the aqueous medium properties includes flow regime of the system and ionic strength (little and lee, 2007).

The next phase of the microbial developmental stage is the migration phase involving the microorganism relocating from the bulk phase to the surface, the initial bacterial attachment is formed by reversible adsorption process while the movement of the bacteria is affected by kinetic mechanism. The reversible adsorption process is formed by electrostatic attraction, physical forces and hydrophobic interaction. The initial attachment is a crucial step in the overall biofilm development process, whether the cell will adhere to the surface or not depends on the surface properties hydrodynamics and the physiological stage of the microbes, the adhesion force is affected by the physiochemical properties of the substrate and the surface properties of the microbes cell. The attached bacteria are called the sessile which are more important to the MIC process than the planktonic bacteria (Jones and Amy, 2002). The third stage is the phase involving the production of the extracellular polymeric substance (EPS). The sessile organism produces these substances which have a heterogeneous composition that includes exopolysacharides, nucleic acids, proteins, glycoprotein and phospholipids. It has been reported that exo-polysacharrides accounts for $40-95 \%$ of macromolecules in microbial extracellular polymeric substance (Arundhati and Paul, 2008). The EPS promotes the colonization process on the metal surface as it makes it possible for negatively charged bacterial such as SRB to attached to either a negatively or a positively charged surface, the colonization rate of the organism present in the surface differs as it affects the growth rare of the biofilms produced. The microbial transport to the interface is medicated by:

- Diffusion by brownian motion

- Convection by system flow

- Motile movement 


\subsection{Biofilms Strata}

The biofilm development on the surface is an autocatalytic process whereby the initial microbial migration promotes biofilm formation and increases surface irregularities(Al-abbas et al, 2011). Acetic acid is one of the final products of metabolism; they are short chained fatty acids and are very aggressive in the attack of oil pipelines especially when its in colony with other micro organisms, this attack is further accelerated by the addition of chloride which is a major constituent of the presently used chemical biocides by the oil industries. The resulting chloride -rich corrosion products often flakes off from the steel pipelines, thus exposing a fresh surface of the pipeline for another attack. The principal effect of bacteria under aerobic condition is to increase the probability that localized corrosion will be initiated, which means that they can set up proper condition for pitting or crevices corrosion, once its initiated, microbial reactions can maintain proper conditions for continued pit/crevice growth.(Sanders and Hamilton, 1999).

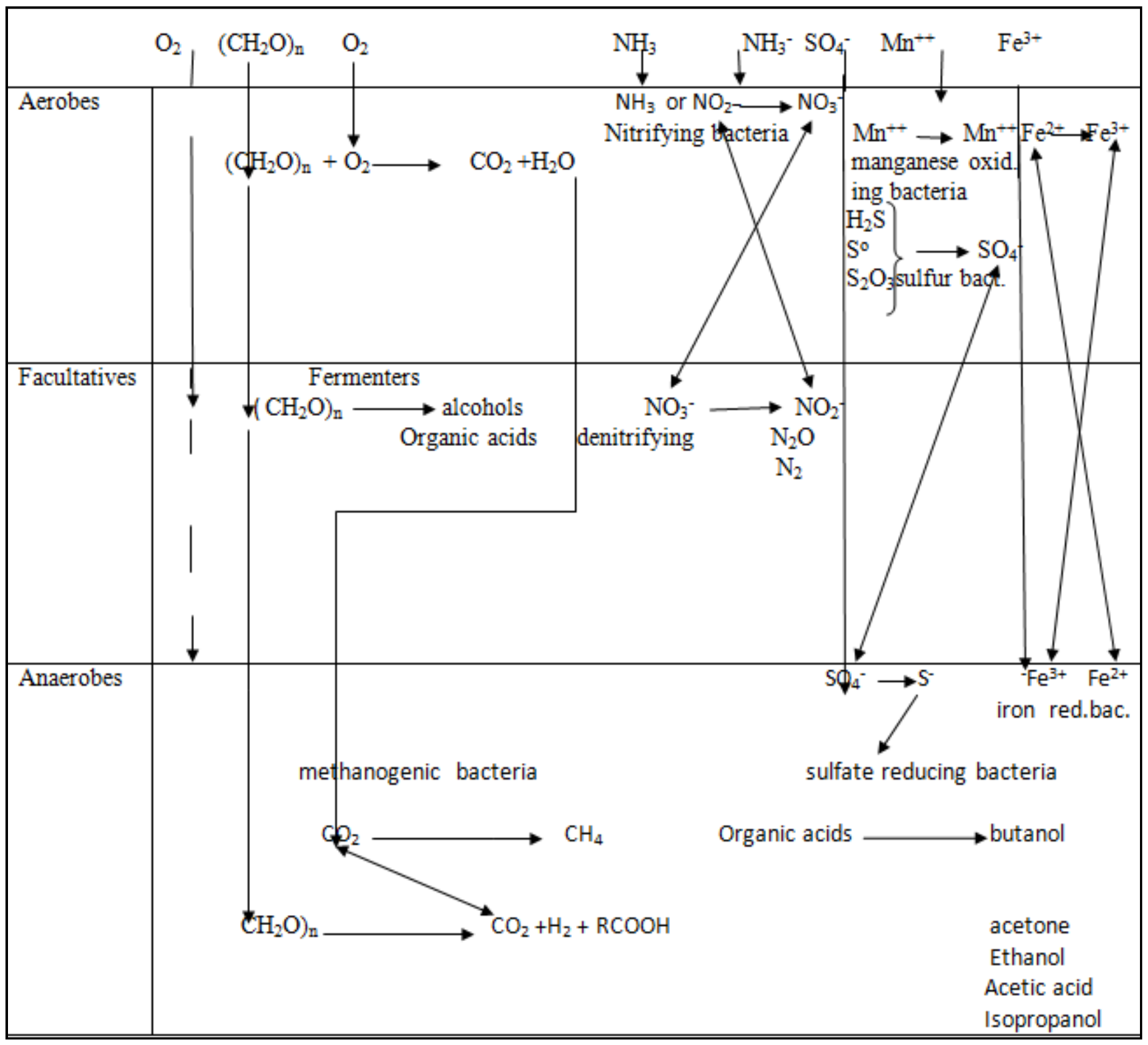

Fig 1.0. Biofilm developmental stata

\subsection{Factors Affecting Biofilm Development}

- Surface Properties

Surface roughness, oxide coverage, chemical composition and polarizations are the surface properties that have an enormous impact on the bacterial attachment and biofilms development. The initial surface roughness could be attributed to the manufacturing defects as in surface irregularities of the pipe. Controversies has erupted as to the influence of the surface roughness on the bacteria attachment process, some literatures reported a higher bacterial colonization and adhesion on high roughness surface while 
other argued that the opposite is truth. (Korber et al, 1997). Surface coverage such as oxides and corrosion products has a detrimental effect on the micro-organism attachment and their effect on metal oxides is one of the research interests for bacteria adhesion. Different oxides can be developed over a surface during the corrosion process e.g. $\mathrm{Fe}_{2} \mathrm{O}_{3}, \mathrm{Cr}_{2} \mathrm{O}_{3}$. Most of these oxides are known for their interest towards bacteria adhesion and provides a firm attachment sites. The metal oxides provides a positively charged surface that can significantly increase bacteria deposition to the surface ( $\mathrm{Li}$ and Began, 2004).

The chemical properties of the surface have been known to directly influence the microorganism adhesion and distribution in biofilms, metals are the most common and economic materials that have been used in an oil and gas pipeline system, bacteria attachment and subsequent biofilms formation can occur on a wide range of metals with different rates.

\section{- Medium Properties}

The medium characteristics such concentration, $\mathrm{pH}$, ionic strength can influence microbial settlement potential.( Javaherdashri, 2010).Commonly at a neutral PH, bacteria are negatively charged but a few strains have been reported to be positively charge. Increasing the cell negative charge will increase the repulsion against a negative charged surface subsequently decreasing bacterial attachment. (sheng et al, 2008).In general increasing the total ionic strength will provide more nutrient and hence increase the bacterial colonization. The effect of nutrients on bacterial colonization was evaluated on a pipeline surface to their ability to grow towards turbidity in water colum and the deposition on the surface increased with the density of the suspended cells, moreover carbon limitation were shown to influence the adhesion strength of attached bacterial (Madigan, 2009). Limitations of macro element adversely impedes the growth of most organisms, it therefore results in lower amount of produced EPS and a thinner biofilms.

\section{- Micro-Organism Properties}

Microbial cell characteristics have a significant role in the adhesion process, the cell surface protects the microbes and provides structural support, microbial cells can be gram positive or gram negative microbes and the difference between them is related to their cell wall configuration. A great majority of microbial cell in the environment tends to be gram negative during adhesion process and the gram positive bacteria will be more attached to the negatively charged surface (Madigan, 2009). It has been shown that proteinaceous appendages including pili and flagella initiates bacterial adhesion by establishing bridges between surfaces and cells . A class of diffusible molecules known as nacylated homoserine lactones which are released by the bacteria into the local environment can interact with neighboring cells in a form of chemical communication (Davis, 2003).

The objective of this study is to investigate the corrosion behavior and calculate the weight loss of the steel coupons $(1.27 \mathrm{~cm} \times 7.62 \mathrm{~cm} \times 0.16 \mathrm{~cm})$ inserted into the experimental pipeline containing the SRB cultivated oil field samples belonging to Agip in Bayelsa State, Nigeria.

\section{Materials and Methods}

\section{Bacteria Culture Using Anaerobic Medium}

The agar prepared for the bacteria culture was an anaerobic medium which contains per litre of distilled water $0.5 \mathrm{~g} \mathrm{~K}_{2} \mathrm{HPO}_{4}, 2 \mathrm{~g}$ yeast extract, $0.3 \mathrm{~g} \mathrm{KH}_{2} \mathrm{PO}_{4}, 0.1 \mathrm{~g} \mathrm{KCl}, 0.2 \mathrm{~g}$ $\mathrm{CaCl}_{2} .2 \mathrm{H}_{2} \mathrm{O}, 0.5 \mathrm{~g} \mathrm{NH}_{4} \mathrm{Cl}, 0.5 \mathrm{~g} \mathrm{MgCl}_{2} .6 \mathrm{H}_{2} \mathrm{O}, 30 \mathrm{~g} \mathrm{NaCl}, 0.7 \mathrm{~g}$ $\mathrm{HCl}, 0.5 \mathrm{mg}$ resazurin, and the medium was boiled under a stream of oxygen free nitrogen gas and cooled to room temperature and the $\mathrm{pH}$ is 7.4. The mixture (oil and water) was separated from the sample by keeping it at $40^{\circ} \mathrm{C}$ for 60 minutes while allowing the water to settle at the bottom of the serum bottle The $\mathrm{pH}$ of the water was adjusted by the addition of $1 \mathrm{~mol} / \mathrm{L}$ of $\mathrm{NaOH}$ and was read on a $\mathrm{pH}$ read as 7 , the serial dilution procedures was employed in inoculating the water samples and was placed in the incubator for 21days

The medium after incubation was dispensed into five anaerobic experimental pipe and the respective biocides (formaldehyde, polyamine, diamine, biguanide and cow urine) at different concentration ranging from $5 \mathrm{mg} / 1$ to $580 \mathrm{mg} / \mathrm{l}$ was injected into each of the pipes on weekly basis and respective weight loss recorded weekly. Five steel coupons weighing $49.60 \mathrm{~g}$ each was inserted downstream inside the pipe, the experimental pipes were washed with detergents, rinsed with distilled water and autoclaved. The coupons were degreased with ethanol and rinsed with acetone before insertion; the pipes were run in a circulation mode for one day (1 day) under anaerobic condition and then inoculated The test coupons at the end of every successive week were washed with distilled water and degreased with acetone, dried and weighed and the weight loss obtained before putting it back. The incubation period lasted for 90 days and the experimental set up dismantled.

Statistical procedures were also used to determine the correlation coefficient, coefficient of determination and polynomial equation generated on the basis of related information.

\section{Results and Discussions}

After the incubation period of 21days, the development of black color becomes visible and also a repulsive smell like that of a rotten egg was equally noticed. The image of the inoculated medium shows the presence of black film which confirms the presence of iron sulfide (FeS) precipitate in conjunction with the presence of hydrogen sulfide that has a repulsive smell like that of a rotten egg. The observations above gave rise to the conclusion that sulphate reducing bacterial (SRB) are responsible for the corrosion.

\section{Corrosion Weight Loss of the Biocides}

The weight loss at the end of each week of the experimental duration for each of the biocide coupon used for the experiment is shown in Table 3.1 


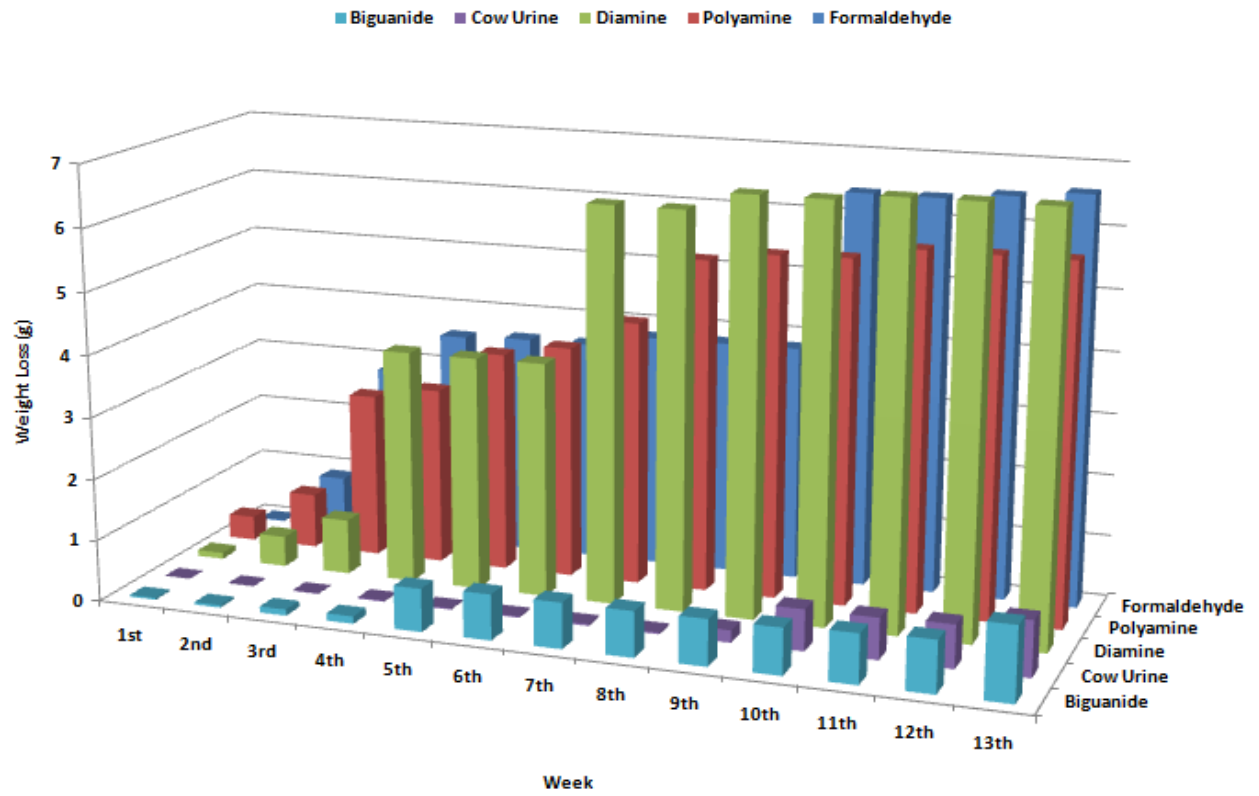

Fig. 3.1. Cumulative Weight Loss of the various Biocides Coupons at varying Concentrations/Weeks.

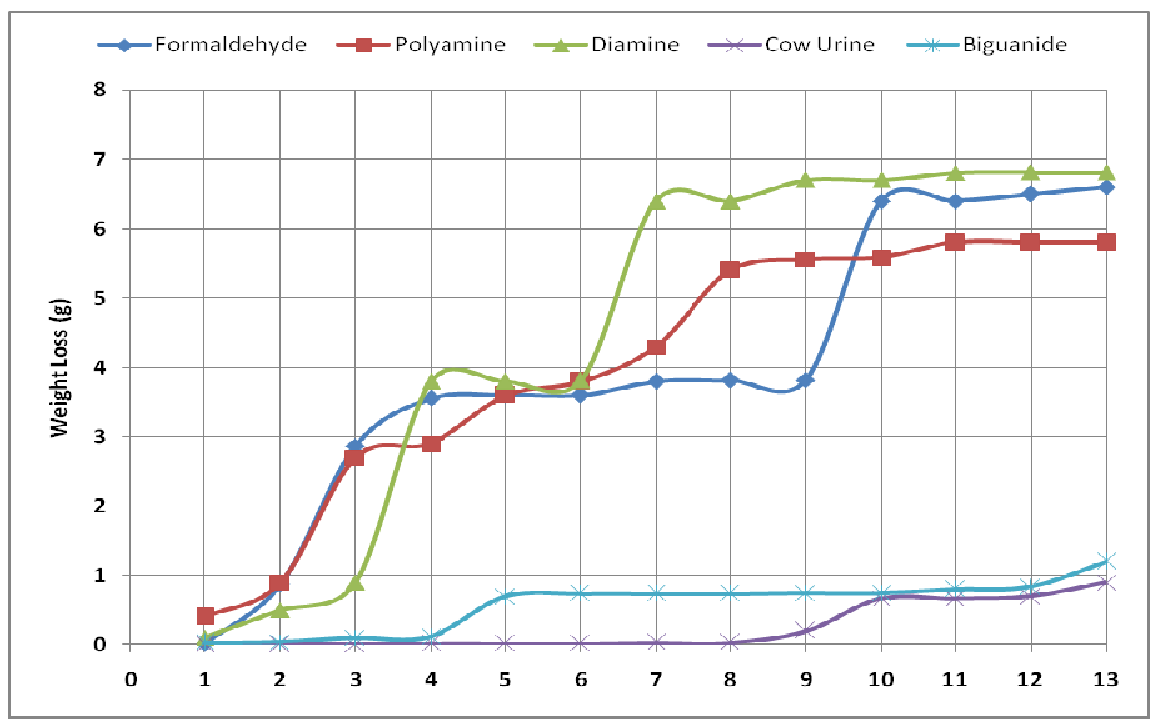

Fig. 3.2. Weight Loss of the coupons for Trendline Determination.

Table 3.1. Weight Loss of the various Biocides Coupons at varying Concentrations/Weeks.

\begin{tabular}{|c|c|c|c|c|c|c|}
\hline \multirow{2}{*}{ Week } & \multirow{2}{*}{$\begin{array}{l}\text { Concen-tration } \\
(\mathrm{mg} / \mathrm{l})\end{array}$} & \multicolumn{5}{|c|}{ Coupons weight loss in (g) for various Biocides } \\
\hline & & Formal-dehyde & Polyamine & Diamine & Cow Urine & Biguanide \\
\hline $1 \mathrm{st}$ & 5 & 0.02 & 0.40 & 0.1 & 0 & 0.03 \\
\hline 2nd & 30 & 0.88 & 0.90 & 0.5 & 0 & 0.04 \\
\hline $3 \mathrm{rd}$ & 80 & 2.87 & 2.70 & 0.9 & 0.01 & 0.1 \\
\hline 4th & 130 & 3.55 & 2.90 & 3.8 & 0.02 & 0.12 \\
\hline 5 th & 180 & 3.60 & 3.60 & 3.8 & 0.02 & 0.7 \\
\hline 6th & 230 & 3.60 & 3.80 & 3.81 & 0.02 & 0.74 \\
\hline 7th & 280 & 3.80 & 4.30 & 6.4 & 0.03 & 0.74 \\
\hline 8th & 330 & 3.81 & 5.40 & 6.4 & 0.03 & 0.74 \\
\hline 9th & 380 & 3.82 & 5.56 & 6.7 & 0.2 & 0.75 \\
\hline 10th & 430 & 6.4 & 5.59 & 6.7 & 0.67 & 0.75 \\
\hline 11 th & 480 & 6.4 & 5.8 & 6.8 & 0.67 & 0.8 \\
\hline 12th & 530 & 6.5 & 5.8 & 6.81 & 0.7 & 0.84 \\
\hline 13th & 580 & 6.6 & 5.8 & 6.81 & 0.9 & 1.2 \\
\hline
\end{tabular}


Table 3.2. Values of $R, R^{2}$ and Models of Biocides for Weight Loss.

\begin{tabular}{llll}
\hline Biocide & $\mathbf{R}$ & $\mathbf{R}^{2}$ & Trendline equation for Weight Loss \\
\hline Formaldehyde & 0.938 & 0.88 & $\mathrm{y}=-0.014 \mathrm{x}^{2}+0.696 \mathrm{x}+0.000$ \\
Polyamine & 0.989 & 0.979 & $\mathrm{y}=-0.043 \mathrm{x}^{2}+1.062 \mathrm{x}-0.662$ \\
Diamine & 0.973 & 0.947 & $\mathrm{y}=-0.065 \mathrm{x}^{2}+1.541 \mathrm{x}-2.055$ \\
Cow Urine & 0.957 & 0.916 & $\mathrm{y}=0.011 \mathrm{x}^{2}-0.078 \mathrm{x}+0.105$ \\
Biaguanide & 0.918 & 0.843 & $\mathrm{y}=-0.005 \mathrm{x}^{2}+0.156 \mathrm{x}-0.200$ \\
\hline
\end{tabular}

Tables 3.1 and Fig. 3.1 revealed that the coupons subjected to various biocides treatment show a different degree of weight loss depending on surrounding conditions. It is observed that the sulphate reducing bacteria reacts differently in the respective medium in which they exist. The pipe containing the cow urine medium showed a negligible weight loss of $0.9 \mathrm{~g}$ during the period under study compared to the losses in other coupons treated with the other biocides.

Fig 3.2 shows the weight loss of the coupons and their polynomial equations trendline while Table 3.2 shows the values of the correlation coefficient $(\mathrm{R})$, coefficient of determination $\left(\mathrm{R}^{2}\right)$ and the polynomial equations for the weight loss of the five coupons treated with the various biocides. The $\mathrm{R}^{2}$ values for each of the biocides were close to 1 which indicates a good measure that future outcomes are likely to be predicted well by the developed models. Specifically, from the models developed, the degree of correlation for formaldehyde, polyamine, diamine, cow urine and biaguanide are $93.8 \%, 98.9 \%, 97.3 \%, 95.7 \%$ and $91.8 \%$. This means that the models results can come out true to reality up to the above percentages when applied.

\section{Conclusion}

Conclusively, the activities of the sulphate reducing bacteria necessitated the weight losses encountered in the coupons placed various medium. The rate of metal loss on the coupons as was calculated is less in experimental pipe with cow urine treatment than in any of the biocides used for this study .Hence the activities of the sulphate reducing bacteria on oil facilities is of a adverse results.

\section{References}

[1] Al-Abbas, F., Kakpovbia, A., Mishra, B., Olson, D., (2011). Utilization of Non-destructive electrochemical techniques in characterizing microbiologically influenced corrosion of AP1 - X512 carbon line -pipe: laboratory study, proc. QNDE Conference, Burlington, VT, USA.

[2] Arunduhati, P., and Paul, A.K., (2008) microbial extracellular polymeric substances central elements in heave metal bioremediation. Indian Journal of Microbiology, 48, 49-60. colloids and interface science 2,256-264
[3] Davis, D. (2003) small-scale system for in vivo dung delivery, Hamilton, W.A (1983) Sulphate Reducing Bacteria and the Offshore Oil Industry, Trends Biotechnology, New York.

[4] Javaherdashri, R., (2010).MIC and cracking of mild and stainless and steel, VDM, verlage, Germany

[5] Jones, D.A., and Army, P.S., (2002), A thermodynamic Interpretation of Microbially influenced corrosion. Corrosion, $58,938,-945$

[6] King, R.A and Miller, J.D (1971) Corrosion by Sulphate Reducing Bacteria, Academic Press, New York.

[7] Korber, D.R., Choi, A., Wolfaardu, G.M., (1997). Substratum topography Influences susceptibility of salmonella enteritidis biofilms to trisodium phosphate Applied enviromental microbial.63

[8] Li, B and Logan, B.E., (2004). Bacterial adhesion to glass and metal oxides Surfaces, colloids and surfaces, Bio interface 26, 81-90.

[9] Little, B. and Lee, J., (2007) Microbially influenced corrosion, Wiley - interscience.

[10] Madigan, M. (2009), Brock biofilm of Micro-organism, $12^{\text {th }}$ Edition, Pearson Benjamin Cummings, San Francisco, USA.

[11] Mansfield, F. (2007) the interaction of bacteria and metal surface, Electrochemist area.Nat. rev. drug discoveries, 2,114122.

[12] Pankhurst E.S (1997). The isolation and enumeration of SRB. In shapton D.A Board, R.G edition Isolation of anaerobes. The society for applied bacteriology Technical Series, No.5 academic press.

[13] Sander, P.F and Hamilton, W.A (1999), Biological and Corrosion activities of Sulphate reducing bacteria in Industrial process plant biological corrosion, NACE $8^{\text {th }}$ Edition Dexter Publisher PP 47 - 68

[14] Sheng, X., Yen, P.T., Phehicocen, S.O (2008).The influence of ionic strength, nutrients and $\mathrm{pH}$ on bacteria adhesion to metals, Journals of Surfaces, colloids and surfaces, Bio interface 26, 81-90.

[15] Thomas, M. (1994). The Isolation and Cultivation of SRB, Journals of General Microbiology 3:46-59 